RASĀYAN J. Chem.

Vol. 13 | No. 3 |1653-1661| July - September | 2020 ISSN: 0974-1496 | e-ISSN: 0976-0083 | CODEN: RJCABP

\title{
SN-DONOR TRIAZINE-3(2H)-THIONE CHELATING LIGAND AND TRANSITION METAL COMPLEXES: SYNTHESES, CHARACTERIZATION, In Vitro ANTIBACTERIAL EVALUATION AND ELECTROCHEMICAL BEHAVIOUR
}

\author{
Manoj Kumar ${ }^{1, *}$, Tanuja Kumari², Jyoti Joshi ${ }^{2}$, Sunil Chhimpa ${ }^{2}$, P.J. John², \\ Raj Rajeshwar Malinda ${ }^{3}$ and Bidya S. Joshi ${ }^{1, *}$ \\ 1,* Department of Chemistry, University of Rajasthan, Jaipur-302004, Rajasthan India. \\ ${ }^{2}$ Department of Chemistry, Malaviya National Institute of Technology, Jaipur-302017, \\ Rajasthan, India. \\ ${ }^{2}$ Department of Zoology, Centre for Advanced Studies, University of Rajasthan, Jaipur-302004, \\ Rajasthan, India. \\ ${ }^{3}$ NUS Lifesciences Private Limited, Ghaziabad, Uttar Pradesh 201102, India. \\ *E-mail: kmanoj.ru@gmail.com
}

\begin{abstract}
Triazine-based heterocycles constitute a class of pertinent heterocyclic compounds that are found ubiquitously in numerous pharmaceuticals, functional materials, and chiral catalysts or ligands. The synthesis and further physicochemical assessment of metal complexes viz. $\left[\mathrm{Cu}(\mathrm{ptt})_{2}\right]_{2},\left[\mathrm{Ni}(\mathrm{ptt})_{2}\right]_{2} \cdot 2 \mathrm{H}_{2} \mathrm{O},\left[\mathrm{Zn}(\mathrm{ptt})_{2}\right] \cdot 2 \mathrm{H}_{2} \mathrm{O},\left[\mathrm{Cd}(\mathrm{ptt})_{2}\right] \cdot 2 \mathrm{H}_{2} \mathrm{O}$ (PTTH: 5-Phenyl-1,2,4-triazine-3(2H)-thione) are delineated in this account. The prepared complexes were identified quantitatively and qualitatively by a variety of physicochemical techniques, namely elemental analysis, FT-IR, LC-MS and ${ }^{1} \mathrm{HNMR}$ spectroscopy. Spectral data show that $\mathrm{Cu}$ and $\mathrm{Ni}$ complexes comprise a binuclear framework, in which the organic molecule simulates as a mono-functional bidentate $S N$ - donor and with two of the four moieties of the molecule performing a bridge to coordinates the central metal ions with the sulphur atom while a mononuclear structure is obtained in the $\mathrm{Zn}^{\mathrm{II}}$ and $\mathrm{Cd}^{\mathrm{II}}$ complexes. Subsequently, FT-IR and LC-MS spectra also confirmed the coordinated aqua molecules in the $\mathrm{Ni}^{\mathrm{II}}, \mathrm{Zn}^{\mathrm{II}}$ and $\mathrm{Cd}^{\mathrm{II}}$ complexes. The ligand and its complexes exhibited considerable antimicrobial activities against the Gram-positive bacteria (Bacillus subtilis: MTCC-121) as well as Gram-negative bacteria (Escherichia coli: MTCC-40). In the present study, $\mathrm{Ni}^{\mathrm{II}}$ complex showed the highest antibacterial activity with $33 \mathrm{~mm}$ diameter of zone of inhibition. Electrochemical reduction behavior of ligand (PTTH), $\mathrm{Cu}^{\mathrm{II}}$ and $\mathrm{Ni}^{\mathrm{II}}$ complexes was explored at glassy carbon electrode using cyclic voltammetry.

Keywords: Triazine, Transition Metal Complex, Spectra, Antimicrobial Activity, Inhibition Zone, Cyclic Voltammetry.
\end{abstract}

(C) RASĀYAN. All rights reserved

\section{INTRODUCTION}

Numerous compounds containing 1,2,4-triazine having various substituents thereon have heretofore been prepared and suggested for use in different ultimate applications, for instance as antihypertensive ${ }^{1}$, antidepressant $^{2}$, analgesic ${ }^{3}$, hypnotic ${ }^{4}$, antibacterial ${ }^{5-6}$, antifungal ${ }^{7-8}$, anti-inflammatory ${ }^{8-9}$, antiviral ${ }^{10-11}$, anthelmintic $^{12}$, antimalarial ${ }^{13}$, anticancer ${ }^{14}$ and chemotherapeutic agents ${ }^{15-17}$ etc. Their versatile coordination chemistry of mercapto substituted triazines, which is owed to their hard $\mathrm{N}$ and soft $\mathrm{S}$ hetero atoms, render these elements the paragon candidates for ascertaining novel morphological, biological, electronic, magnetic and spectroscopic properties, additionally ways of reactivity and catalysis. One archetypical class of ligand family in this context is the one of prime chelating heterocyclic thioamide ligand having SN- coordination mode the 5-aryl-1,2,4-triazine-3(2H)-thione is especial in coordination chemistry owing to potential hard donor atom $\mathrm{N}$ as well as one soft donor atom $\mathrm{S}$, apart from the possibility of existence in both tautomeric forms (thione v/s thiol, Fig.-1). The parent ligand adopts the Rasayan J. Chem., 13(3), 1653-1661(2020)

http://dx.doi.org/10.31788/RJC.2020.1335846

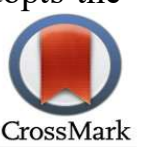


RASĀYAN J. Chem.

Vol. 13 | No. 3 |1653-1661| July - September | 2020

thione form in the solid and the thiol form in some solutions. In their anionic mode, both the thionate sulfur and thioamide nitrogen atom are functional to coordinate with metal centers in several manners, according to the "Pearson's principle", as a N,S-bidentate chelating agent or as an individual basis deprotonated bidentate anions or as a bridging agent between two metal centers. Therefore, there is indeed a tunable capability for adopting various co-ordinations mode with the panoptic range of metal ions, to give stable, intensely colored and biologically active metal derivatives. Furthermore, due to the electronic delocalization, which is strengthened on deprotonation, these ligands are immensely versatile. This fact, together with the presence of different kinds of donor atoms like N, or S, several coordination modes are possible which subjected to the metal coordination preferences; therefore, a specific ligand can demonstrate different coordination behaviour ${ }^{18-21}$. Moreover, triazine derivatives have traditionally found utile applications in electrochemical science as multi-step oxidation-reduction systems during exploration from cyclic voltammetry. ${ }^{16,22-25}$

We thus, set out to characterize the chelation properties and propensity of 5-Phenyl-1,2,4-triazine-3(2H)thione (PTTH) toward the formation of a variety of transition metal complexes over the insertion of metal ion $\left(\mathrm{M}^{\mathrm{II}}=\mathrm{Ni}, \mathrm{Cu}, \mathrm{Zn}, \mathrm{Cd}\right)$ in a more systematic fashion. These compounds were carried out to evaluate the antibacterial activities against Gram (+) and Gram (-) Human bacteria. All newly synthesized compounds exhibited a high degree of inhibition zone towards both tested Human pathogenic microorganisms. Besides, the electrochemical properties of ligand and metal complexes have been examined in DMF at a glassy carbon working electrode employing an electrochemical analyser to monitor the structural changes along with electron transfer.

\section{EXPERIMENTAL}

\section{Materials and Methods}

Thiosemicarbazide (98\%) was purchased commercially source from Sigma- Aldrich. The starting material phenylglyoxal hydrate was prepared as standard method ${ }^{26}$. Solvents were dried before using according to standard procedure ${ }^{27}$. The transition metal salts used were in their hydrated form as received and double distilled water was used throughout the study. The melting point of the synthesized compounds was determined by the 'melting point apparatus' using the air atmosphere. FT-Infrared Spectra of ligand and its transition metal complexes were taken in dry $\mathrm{KBr}$ pellets using in the range $400-4000 \mathrm{~cm}^{-1}$ with a SHIMADZU model 8400 FT-IR spectrophotometer. ${ }^{1} \mathrm{H}$ (300.1 MHz) Nuclear Magnetic Resonance spectra were collected on a Bruker 300 NMR spectrometer in DMSO-d $\mathrm{d}_{6}$ solution using TMS as an internal reference. LC-MS spectra of compounds were recorded with a Waters Q-TOF micro mass. Carbon, hydrogen, nitrogen and sulphur were analyzed with an elemental analyser. Standard Gravimetric methods were employed to find out the metal contents ${ }^{27}$. All the compounds (1-5) have been screened against pathogenic bacterial strains of Bacillus subtilis (MTCC-121) and Escherichia coli (MTCC-40) by disc diffusion assay method ${ }^{30-31}$. Electrochemical assessments were performed with model $1230 \mathrm{~A}$ [SR 400] (CHI instrument, Bee Cave, TX, USA) electrochemical analyzer using glassy carbon as the working electrode, a platinum wire as the auxiliary electrode (counter electrode), and $\mathrm{Ag} / \mathrm{AgCl}$ as the reference electrode. Cyclic voltammetry studies of neat ligand, $\mathrm{Ni}^{\mathrm{II}}$ and $\mathrm{Cu}^{\mathrm{II}}$ complexes were carried out on $0.001 \mathrm{M}$ solutions in dimethylformamide containing $0.1 \mathrm{M} \mathrm{KCl}$ as the supporting electrolyte; double distilled water, obtained from laboratory distillation assembly was used to prepare Britton-Robinson (BR) buffer solution of different $\mathrm{pH}$ (2 to 10$)$ used throughout the voltammetric study.

\section{Pre-treatment of the Glassy Carbon Electrode}

The working electrode was polished before each experiment with Alumina slurry in water to furnish the reproducible electrode surface and to ameliorate sensitivity and resolution of voltammetric elevations. The procedure was performed at room temperature and a nitrogen atmosphere was maintained over the solution during the measurements.

\section{Synthesis of Ligand (PTTH)}

5-Phenyl-1,2,4-triazine-3(2H)-thione was synthesized by reported procedure ${ }^{28-29}$ with some modifications. A mixture of phenylglyoxal hydrate $(1.52 \mathrm{~g} ; .01 \mathrm{M})$, thiosemicarbazide $(1.00 \mathrm{~g} ; .011 \mathrm{M})$ and $10 \%$ aqueous solution of potassium carbonate was refluxed at $30-35^{\circ} \mathrm{C}$ temperature for $1 / 2 \mathrm{hr}$. After cooling the solution acidified with hydrochloric acid, a red precipitate was obtained which crystallized from ethanol and water 
RASĀYAN J. Chem.

Vol. 13 | No. 3 |1653-1661| July - September | 2020

(1:1) in red needles with M. P. $197-199^{\circ} \mathrm{C}$ in just about quantitative yield; $\mathrm{C}_{9} \mathrm{~N}_{3} \mathrm{H}_{7} \mathrm{~S}$. ${ }^{1} \mathrm{HNMR}(300 \mathrm{MHz}$, DMSO-d $)_{6}: \delta(\mathrm{ppm})=9.7(1 \mathrm{H}, \mathrm{N}=\mathrm{CH}), 11.9(1 \mathrm{H}, \mathrm{NH}), 7.4-8.2(5 \mathrm{H}, \mathrm{Ph}) . \mathrm{IR}\left(\mathrm{KBr}, \mathrm{cm}^{-1}\right): 3163(\mathrm{~N}-\mathrm{H})$, $1540(\mathrm{~N}=\mathrm{N}), 1595(\mathrm{C}=\mathrm{N}), 2610 \mathrm{w}(\mathrm{S}-\mathrm{H})$.

\section{Synthesis of Metal Complexes (1:2)}

The complexes were prepared by treating the methanolic solution of chlorides of $\mathrm{Ni}^{\mathrm{II}}\left(\mathrm{NiCl}_{2} \cdot 6 \mathrm{H}_{2} \mathrm{O}\right.$ $(0.190 \mathrm{~g} ; 0.80 \mathrm{mmol}), \mathrm{Cu}^{\mathrm{II}}\left(\mathrm{CuCl}_{2} .2 \mathrm{H}_{2} \mathrm{O}(0.137 \mathrm{~g} ; 0.80 \mathrm{mmol})\right), \mathrm{Zn}^{\mathrm{II}}\left(\mathrm{ZnCl}_{2}(0.108 \mathrm{~g} ; 0.80 \mathrm{mmol})\right)$, and $\mathrm{Cd}^{\mathrm{II}}$ $\left(\mathrm{CdCl}_{2} . \mathrm{H}_{2} \mathrm{O}(0.161 \mathrm{~g} ; 0.80 \mathrm{mmol})\right)$ with methanolic solution of ligand (PTTH; $\left.0.304 \mathrm{~g}, 1.60 \mathrm{mmol}\right)$, stirred under reflux for $5-6 \mathrm{hrs}$. at $35-40^{\circ} \mathrm{C}$ temperature. Subsequently, they were validated by TLC using ethyl acetate and petroleum ether $(1: 2 \mathrm{v} / \mathrm{v})$ as the eluent, and the resulting solids were filtered off and washed with methanol several times and finally recrystallized from ethanol and left to dry over $\mathrm{P}_{4} \mathrm{O}_{10}$.


$47.81 \%$ ); H, 3.11\% (found 3.08\%); N, 18.55\% (found $18.58 \%$ ); S, $14.15 \%$ (found $14.10 \%$ ); Ni, $12.95 \%$ (found 12.89\%). ${ }^{1} \mathrm{HNMR}\left(300 \mathrm{MHz}, \mathrm{DMSO}^{-} \mathrm{d}_{6}\right): \delta(\mathrm{ppm})=8.1(\mathrm{~s}, 1 \mathrm{H}, \mathrm{N}=\mathrm{CH}), 7.0-7.7(\mathrm{~m}, 5 \mathrm{H}, \mathrm{Ph}) . \mathrm{m} / \mathrm{z}$ (LC-MS, \%relative abundance): 905(27.00), 900(10.00), 623(9.00), 436(100.00), 252(6.00), 145(18.00), 103(20.00). IR $\left(\mathrm{KBr}, \mathrm{cm}^{-1}\right): 1525(\mathrm{~N}=\mathrm{N}), 1575(\mathrm{C}=\mathrm{N}), 825(\mathrm{C}-\mathrm{S})$.

[Cu(ptt) $\left.)_{2}\right]_{2}$ : Beige solid; Yield 63\%; mp 215-218 ${ }^{\circ} \mathrm{C} ;\left(\mathrm{CuC}_{18} \mathrm{H}_{12} \mathrm{~N}_{6} \mathrm{~S}_{2}\right)_{2}$; Calcd. C, 49.13\% (found 49.11\%); $\mathrm{H}, 2.75 \%$ (found $2.71 \%$ ); $\mathrm{N}, 19.10 \%$ (found 19.14\%); $\mathrm{S}, 14.57 \%$ (found $14.55 \%$ ); $\mathrm{Cu}, 14.44 \%$ (found $14.42 \%) . \mathrm{m} / \mathrm{z}$ (LC-MS, \%relative abundance): 878(9.00), 815(73.00), 628(30.00), 471(16.00), 439(100.00), 252(6.00), 145(63.00), 104(39). IR $\left(\mathrm{KBr}, \mathrm{cm}^{-1}\right): 1535(\mathrm{~N}=\mathrm{N}), 1580(\mathrm{C}=\mathrm{N}), 820(\mathrm{C}-\mathrm{S})$.

[Zn(ptt) $\left.)_{2}\right] .2 \mathrm{H}_{2} \mathrm{O}$ : Pale-yellow solid; Yield 41\%; mp 212-215 ${ }^{\circ} \mathrm{C} ; \mathrm{Zn}_{(}\left(\mathrm{C}_{9} \mathrm{H}_{6} \mathrm{~N}_{3} \mathrm{~S}\right)_{2} .2 \mathrm{H}_{2} \mathrm{O}$. Calcd. C, 45.24\% (found $45.28 \%$ ); $\mathrm{H}, 3.37 \%$ (found $3.39 \%$ ); N, 17.59\% (found 17.55\%); S, 13.42\% (found $13.43 \%$ ); Zn, $13.68 \%$ (found 13.64\%). ${ }^{1} \mathrm{HNMR}\left(300 \mathrm{MHz}, \mathrm{DMSO}-\mathrm{d}_{6}\right): \delta(\mathrm{ppm})=7.9(\mathrm{~s}, 1 \mathrm{H}, \mathrm{N}=\mathrm{CH}), 6.9-7.3(\mathrm{~m}, 5 \mathrm{H}$, $\mathrm{Ph}) . \mathrm{m} / \mathrm{z}$ (LC-MS, \%relative abundance): 477(14.00), 274(100.00), 290(20.00), 251(13.00), 359(13.00). IR $\left(\mathrm{KBr}, \mathrm{cm}^{-1}\right): 1535(\mathrm{~N}=\mathrm{N}), 1580(\mathrm{C}=\mathrm{N}), 815(\mathrm{C}-\mathrm{S})$.

[Cd(ptt) $)_{2}$. 2 $2 \mathrm{H}_{2} \mathrm{O}$ : Yellow-green solid; Yield 57\%; mp $>330^{\circ} \mathrm{C} ; \mathrm{Cd}\left(\mathrm{C}_{9} \mathrm{H}_{6} \mathrm{~N}_{3} \mathrm{~S}\right)_{2} .2 \mathrm{H}_{2} \mathrm{O}$. Calcd. C, $41.19 \%$ (found $41.08 \%$ ); $\mathrm{H}, 3.07 \%$ (found $3.09 \%$ ); $\mathrm{N}, 16.01 \%$ (found $16.06 \%$ ); S, $12.22 \%$ (found $12.18 \%$ ); $\mathrm{Cd}$, $21.42 \%$ (found $21.45 \%$ ). ${ }^{1} \mathrm{HNMR}\left(300 \mathrm{MHz}, \mathrm{DMSO}_{\mathrm{d}}\right.$ ): $\delta(\mathrm{ppm})=7.7(\mathrm{~s}, 1 \mathrm{H}, \mathrm{N}=\mathrm{CH}) 7.1-7.3(\mathrm{~m}, 5 \mathrm{H}$, $\mathrm{Ph}) . \mathrm{m} / \mathrm{z}$ (LC-MS, \%relative abundance): 525(41.00), 507(5.00), 429(35.00), 411(6.00), 301(10.00), 222(23.00), 151(100.00), 190(3.00). IR (KBr, $\left.\mathrm{cm}^{-1}\right): 1510(\mathrm{~N}=\mathrm{N}), 1575(\mathrm{C}=\mathrm{N}), 820(\mathrm{C}-\mathrm{S})$.

\section{In vitro Antibacterial Assay}

To screen the biological activities of the ligand (PTTH) and their transition metal complexes, an in-vitro antibacterial assay was employed against the Gram-positive Bacillus subtilis (MTCC-121) and Gramnegative Escherichia coli (MTCC-40) as the method previously described. ${ }^{30-31}$ The concentrations used for the test were $1 \mathrm{mg} / \mathrm{ml}$ and $2 \mathrm{mg} / \mathrm{ml}$ of the compounds.

\section{FT-Infra Red Spectroscopy}

\section{RESULTS AND DISCUSSION}

The significant FT-IR spectral data of the organic molecule and its metal complexes are disclosed in Table 1 showed some characteristic stretching bands at: $3163,1540,1595, \mathrm{~cm}^{-1}$ assigned to $\mathrm{N}-\mathrm{H}, \mathrm{N}=\mathrm{N}$ and $\mathrm{C}=\mathrm{N}$ of triazine ring of free ligand $(\mathrm{PTTH})$, respectively. Additionally, a weak broadband appeared just about $2610 \mathrm{~cm}^{-1}$ due to $v(\mathrm{~S}-\mathrm{H})$ vibrations, tell us that mercapto triazine exhibits thiol-thione tautomerism ${ }^{28}$. Further, in the spectra of all of the complexes, these bands $(\mathrm{N}-\mathrm{H}, \mathrm{S}-\mathrm{H})$ were disappeared. The absence of these bands suggesting the deprotonation of thio triazine molecule and further constitution of fresh $\mathrm{M}-\mathrm{N}$ and $\mathrm{M}-\mathrm{S}$ coordination bond take place during the complexation. This is further authenticated by the appearance of new $v(\mathrm{M}-\mathrm{N}, \mathrm{M}-\mathrm{S})$ bands at $505-550$ and $400-455 \mathrm{~cm}^{-1}$ respectively. The band corresponding to the $\mathrm{C}=\mathrm{S}$ moiety has moved to lower frequencies (by $15-30 \mathrm{~cm}^{-1}$ ) due to 
RASĀYAN J. Chem.

Vol. 13 | No. 3 |1653-1661| July - September | 2020

decreasing of the bond order (and increasing of bond length) of carbon-sulphur bond result from coordination of the $\mathrm{S}$ to central metal ions. Further, the bands of $\mathrm{C}=\mathrm{N}$, and $\mathrm{N}=\mathrm{N}$ of triazine moiety are moved to the lower frequency because of complexation in between, however, the other bands such as $\mathrm{C}=\mathrm{C}, \mathrm{C}-\mathrm{H}$ of phenylic ring did not express any quite shifting because they are not participating in the complexation to the metal ion. Thus, It deduced that the organic molecule chelated through amine $\mathrm{N}$ and thione S-atoms to the metal ion leading to the constitution of four-member chelate ring, and the triazine rings are virtually planar. The appearance of coordinated aqua molecules in the $\mathrm{Ni}^{\mathrm{II}}, \mathrm{Zn}^{\mathrm{II}}$ and $\mathrm{Cd}^{\mathrm{II}}$ complexes are further expressed by a broad through band in the region $3250-3370 \mathrm{~cm}^{-1}$ is assigned.

\section{${ }^{1}$ H-NMR Spectroscopy}

The NMR spectra of the thio 1,2,4-triazine nucleus were reported for ${ }^{1} \mathrm{H}$. The parent compound (PTTH) showed signals at 9.7, 11.9, and 7.4-8.2 ppm (in DMSO- $\mathrm{d}_{6}$ ) which were attributed to $\mathrm{N}=\mathrm{CH}, \mathrm{NH}$, and phenylic protons $(5 \mathrm{H})$. The ${ }^{1} \mathrm{HNMR}$ of all the prepared compounds exhibit a multiplet only in the aromatic zone corresponding to the phenyl ring of the particular compound. ${ }^{1} \mathrm{H}$ NMR spectra of metal complexes indicate the absence of the NH signal which was recorded at $11.9 \mathrm{ppm}$ in the free ligand, supporting the coordination between the metal ion and Nitrogen atom leading to the formation of new $\mathrm{M}-\mathrm{N}$ bond. The fresh M-N coordination in the complexes is too supported by an upfield shift in the position of the proton signal of $\mathrm{N}=\mathrm{CH}$, of the cyclic triazine moiety, compared to the neat ligand.

\begin{tabular}{c|c|c|c|c|c|c|c}
\multicolumn{7}{c}{ Table-1: IR Spectral Data $\left(4000-400 \mathrm{~cm}^{-1}\right)$ of the Ligand and its Complexes } \\
\hline Compound & $\mathrm{v}(\mathrm{N}-\mathrm{H})$ & $\mathrm{v}(\mathrm{C}=\mathrm{N})$ & $\begin{array}{c}\mathrm{v}(\mathrm{C}=\mathrm{S}) \\
\mathrm{v}(\mathrm{C}-\mathrm{S})\end{array}$ & $\mathrm{v}(\mathrm{N}=\mathrm{N})$ & $\mathrm{v}\left(\mathrm{H}_{2} \mathrm{O} / \mathrm{OH}^{-}\right)$ & $\mathrm{v}(\mathrm{M}-\mathrm{N})$ & $\mathrm{v}(\mathrm{M}-\mathrm{S})$ \\
\hline $\mathrm{PTTH}$ & 3163 & 1595 & 840 & 1540 & -- & -- & -- \\
\hline$\left(\mathrm{Cu}(\mathrm{ptt})_{2}\right)_{2}$ & -- & 1580 & 820 & 1535 & -- & 502 & 414 \\
\hline$\left(\mathrm{Ni}(\mathrm{ptt})_{2}\right)_{2} \cdot 2 \mathrm{H}_{2} \mathrm{O}$ & -- & 1575 & 825 & 1525 & 3270 & 510 & 405 \\
\hline $\mathrm{Zn}(\mathrm{ptt})_{2} .2 \mathrm{H}_{2} \mathrm{O}$ & -- & 1580 & 815 & 1535 & 3285 & 522 & 408 \\
\hline $\mathrm{Cd}(\mathrm{ptt})_{2} .2 \mathrm{H}_{2} \mathrm{O}$ & -- & 1575 & 820 & 1510 & 3365 & 500 & 412 \\
\hline
\end{tabular}

\section{LC-MS Spectroscopy}

The prominent molecular ion peaks in the mass spectra of compounds 1 to 5 established the molecular formula and supported the proposed structures (Fig.-2) of the complexes as obtained. The mass spectrum of neat ligand displays the parental ion peak $[\mathrm{M}]^{+}$at $\mathrm{m} / \mathrm{z}=189(78 \%)$ and a weak peak at $\mathrm{m} / \mathrm{z}=190$ due to ${ }^{13} \mathrm{C}$ and/or ${ }^{15} \mathrm{~N}$ isotopes. $\mathrm{Cu}^{\text {II }}$ complex exhibits a molecular ion peak at $\mathrm{m} / \mathrm{z}=878.50$ (calc. $\mathrm{M}$. Wt. $=$ 877.97) with an intensity of $9 \%$ which is equivalent to its molecular weight (Fig.-3). In the mass spectrum of a molecule, peaks are attributed to fragmentation obtained from the rapture of various bonds in a particular molecule. Also, in the mass spectrum of other complexes molecular ion peak observed at $\mathrm{m} / \mathrm{z}=$ 905,477 and 525 are attributed to $\left[\mathrm{Ni}(\mathrm{ptt})_{2}\right]_{2} \cdot 2 \mathrm{H}_{2} \mathrm{O}, \mathrm{Zn}(\mathrm{ptt})_{2} \cdot 2 \mathrm{H}_{2} \mathrm{O}$ and $\mathrm{Cd}(\mathrm{ptt})_{2} \cdot 2 \mathrm{H}_{2} \mathrm{O}$ respectively. $\mathrm{Cu}$ and Ni complexes display a peak corresponding to the fragment $\left[\mathrm{M}_{2} \mathrm{~L}_{3}\right]^{+{ }^{\circ}}$ suggesting a binuclear species. Analytical data further indicating the non-appearance of chloride groups in the compounds. If the complexes bear two metal ions they should contain four molecules of ligand to acquire neutrality. The process to get a binuclear species as it may be because of the formation of the sulfur bridges, take place in many cyclic thiosemicarbazone complexes ${ }^{23-24}$. The mass spectrum of $\mathrm{Cu}^{\mathrm{II}}$ complex expresses a peak regarding to a fragment $\left[\mathrm{Cu}(\mathrm{ptt})_{3}\right]^{+\circ}$ at $628.10(30 \%)$ indicating the existence of a molecule comprising one copper and three deprotonated molecules of the ligand. The base peak at $\mathrm{m} / \mathrm{z}=439.04(100 \%)$ is due to $\mathrm{C}_{18} \mathrm{H}_{12} \mathrm{CuN}_{6} \mathrm{~S}_{2}$. The other positive ions give the peaks at, 471.02, 252, 145, and 103.97 mass numbers. The intensities of these peaks suggest an idea regarding the stabilities of the fragments. Mass spectra of $\mathrm{Zn}$ and $\mathrm{Cd}$ complexes show a peak corresponding to the fragment $\left[\mathrm{Zn}(\mathrm{ptt})_{2}\right]^{+\circ}$, and $\left[\mathrm{Cd}(\mathrm{ptt})_{2}\right]^{+^{\circ}}$ respectively, which indicates the existence a mononuclear comprising one metal ion and two deprotonated molecules of the ligand.

\section{Biological Evaluation}

The ligand (PTTH) and the complexes (2-5) exhibited variable antibacterial activities against both Bacillus subtilis and Escherichia coli, are summarised in Table-2. As expected, Negative control, and 
RASĀYAN J. Chem.

Vol. 13 | No. 3 |1653-1661| July - September | 2020

DMSO, did not exhibit any antibacterial properties. Maximum inhibition activity, thus showed the most effective against E. coli that compounds 1-5 has Zone of Inhibition (ZoI) 33.0, 27.0, 24.0, 22.0 and 21.0 $\mathrm{mm}$, and further B. subtilis has ZoI 13.0, 12.0, 11.0 and $10.0 \mathrm{~mm}$, respectively.



Fig.-1: Tautomerism Form in 1,2,4-triazine (PTTH)
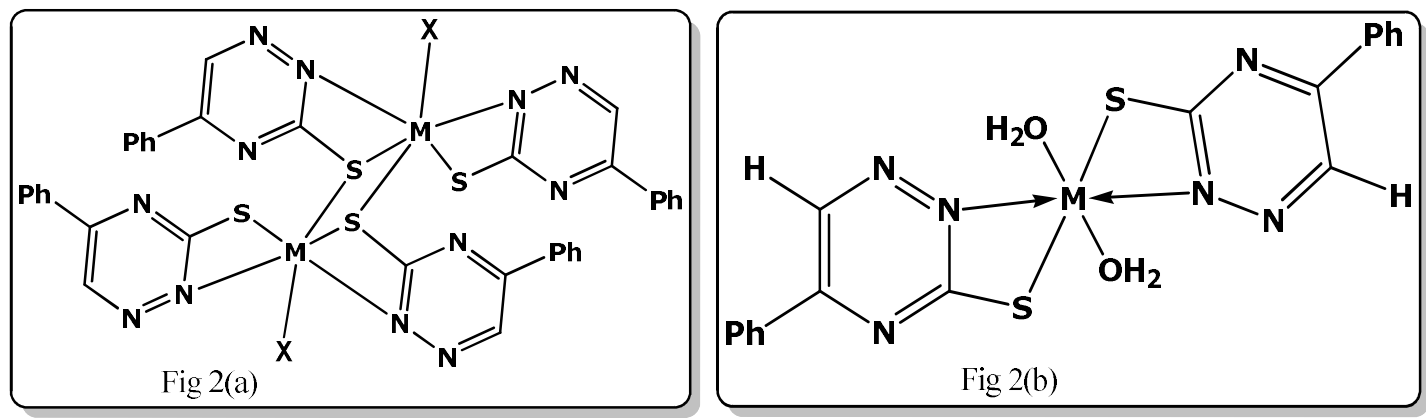

Fig.-2:The Proposed Structures of Metal Complexes (a) $\mathrm{M}=\mathrm{Cu}$, Ni when only $\mathrm{M}=\mathrm{Ni}, \mathrm{X}=\mathrm{H}_{2} \mathrm{O}$ ) and (b) $\mathrm{M}=\mathrm{Cd}, \mathrm{Zn}$ )).

Thus, we observed that, compounds 1-5, with both the stock concentration, were active against both pathogenic bacterial strains. The nickel complex has demonstrated the highest zone of inhibition against E. coli at $33 \mathrm{~mm}$. The disc diffusion assay showed that, compounds 1-5 have antibacterial properties at various concentrations. Comparatively $\mathrm{Ni}^{\mathrm{II}}, \mathrm{Cu}^{\mathrm{II}}, \mathrm{Zn}^{\mathrm{II}}$ and $\mathrm{Cd}^{\mathrm{II}}$ complexes of thio(1,2,4-)triazine have shown wider $\mathrm{ZoI}$ than free ligand, therefore, it does indicate the high spectrum of antibacterial activity against pathogenic strains such as E. coli, of these metal complexes.

Table-2: Inhibition Zone ( $\mathrm{mm}$ ) of Ligand and their Metal Complexes against Pathogenic Bacteria

\begin{tabular}{|c|c|c|c|c|c|c|c|}
\hline \multirow[t]{2}{*}{$\begin{array}{l}\text { S. } \\
\text { No. }\end{array}$} & \multirow[t]{2}{*}{ Compound } & \multirow{2}{*}{$\begin{array}{l}\text { Concentration } \\
\text { of compound } \\
(\mathrm{mg} / \mathrm{ml})\end{array}$} & \multicolumn{2}{|c|}{$\begin{array}{l}\text { Diameter growth of } \\
\text { inhibition zone }(\mathrm{mm})\end{array}$} & \multirow{2}{*}{$\begin{array}{c}\text { Disc } \\
\text { Diameter } \\
\text { (in } \mathrm{mm} \text { ) }\end{array}$} & \multirow[t]{2}{*}{$\begin{array}{l}\text { Antibacterial } \\
\text { activity }\end{array}$} & \multirow[t]{2}{*}{$\begin{array}{c}\text { DMSO } \\
\text { (Control) }\end{array}$} \\
\hline & & & E. coli & B. subtilis & & & \\
\hline 1 & PTTH & $\begin{array}{l}1 \\
2\end{array}$ & $\begin{array}{l}14 \\
21\end{array}$ & $\begin{array}{l}12 \\
13\end{array}$ & 6 & $\begin{array}{c}++ \\
+++\end{array}$ & \multirow{5}{*}{$\begin{array}{c}\text { No } \\
\text { Activity } \\
\text { Found }\end{array}$} \\
\hline 2 & $\begin{array}{l}\left(\mathrm{Ni}(\mathrm{ptt})_{2}\right)_{2} . \\
2 \mathrm{H}_{2} \mathrm{O}\end{array}$ & $\begin{array}{l}1 \\
2\end{array}$ & $\begin{array}{l}30 \\
33\end{array}$ & $\begin{array}{l}09 \\
12\end{array}$ & 6 & $\begin{array}{l}++++ \\
++++\end{array}$ & \\
\hline 3 & $\left(\mathrm{Cu}(\mathrm{ptt})_{2}\right)$ & $\begin{array}{l}1 \\
2\end{array}$ & $\begin{array}{l}15 \\
22\end{array}$ & $\begin{array}{l}08 \\
10\end{array}$ & 6 & $\begin{array}{c}+++ \\
++++\end{array}$ & \\
\hline 4 & $\begin{array}{c}\mathrm{Zn}(\mathrm{ptt})_{2} . \\
2 \mathrm{H}_{2} \mathrm{O}\end{array}$ & $\begin{array}{l}1 \\
2\end{array}$ & $\begin{array}{l}18 \\
27\end{array}$ & $\begin{array}{l}11 \\
12\end{array}$ & 6 & $\begin{array}{c}+++ \\
++++\end{array}$ & \\
\hline 5 & $\begin{array}{c}\mathrm{Cd}(\mathrm{ptt})_{2} \cdot 2 \\
\mathrm{H}_{2} \mathrm{O}\end{array}$ & $\begin{array}{l}1 \\
2\end{array}$ & $\begin{array}{l}22 \\
24\end{array}$ & $\begin{array}{l}08 \\
11\end{array}$ & 6 & $\begin{array}{l}++++ \\
++++\end{array}$ & \\
\hline
\end{tabular}

$(-)=$ no inhibition; $(+)=$ zone size $6-8 \mathrm{~mm} ;(++)=$ zone size $9-14 \mathrm{~mm} ;(+++)=$ zone size $15-20 \mathrm{~mm} ;(++++)=$ zone size $>20 \mathrm{~mm}$ 
RASĀYAN J. Chem.

Vol. 13 | No. 3 |1653-1661| July - September | 2020

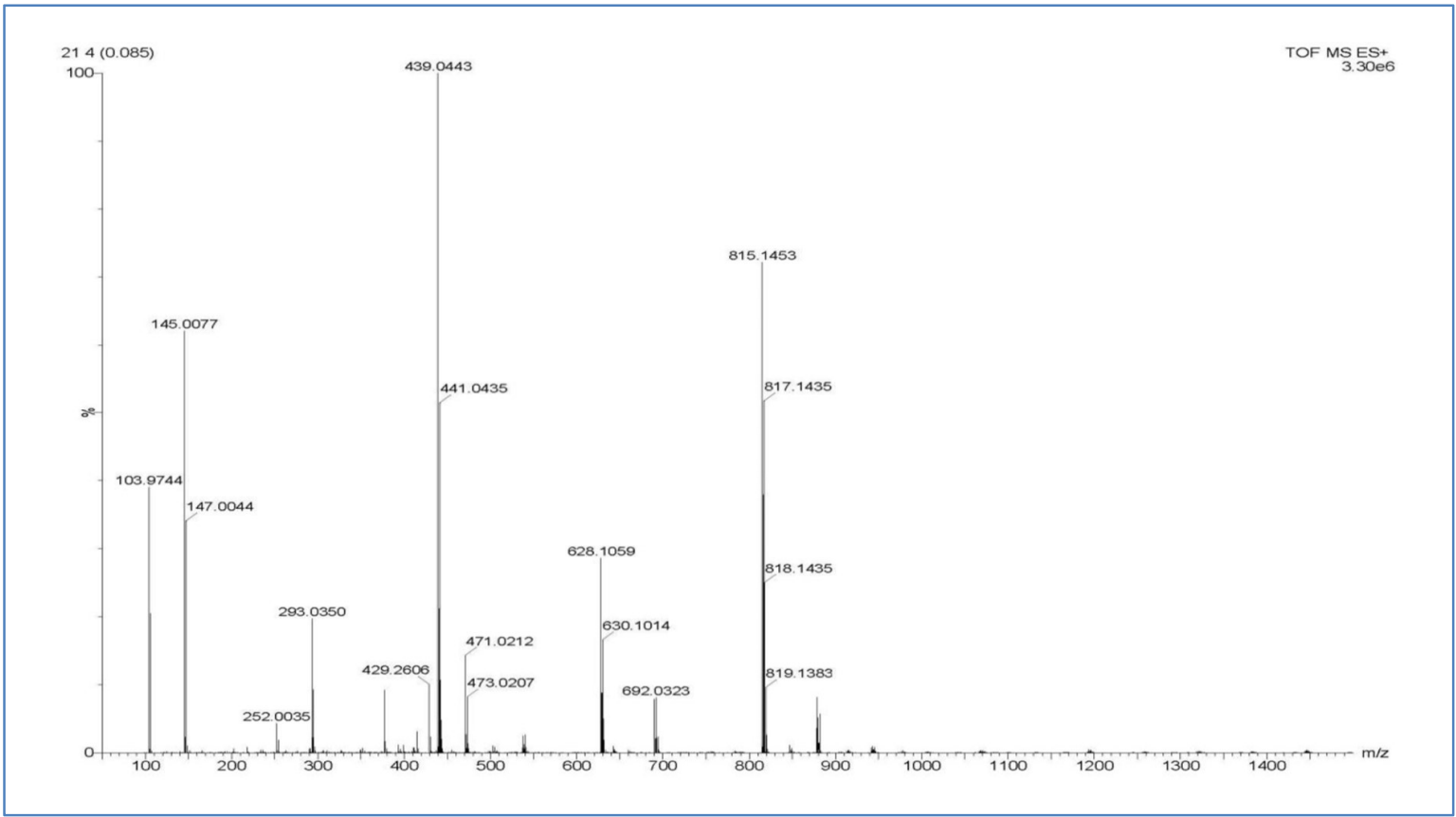

Fig.-3: LC-MS Spectrum of $\left[\mathrm{Cu}(\mathrm{ptt})_{2}\right]_{2}$

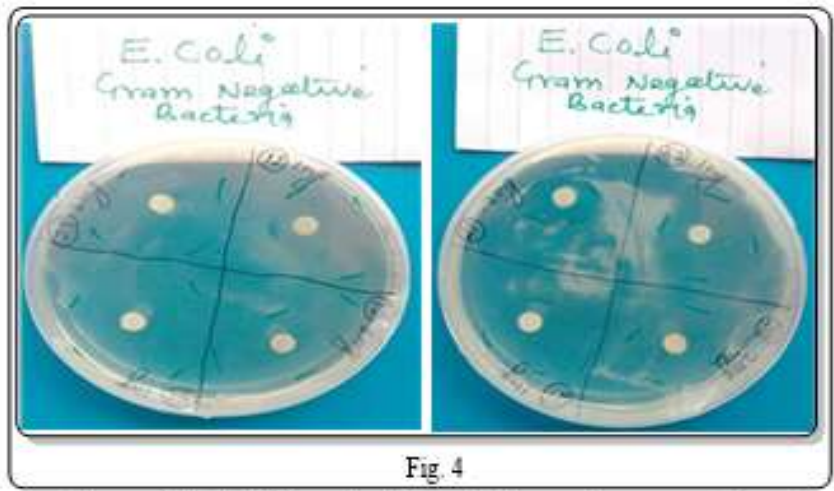

Fig.-4: Zone of Inhibition for Metal Complexes against $E$. coli.

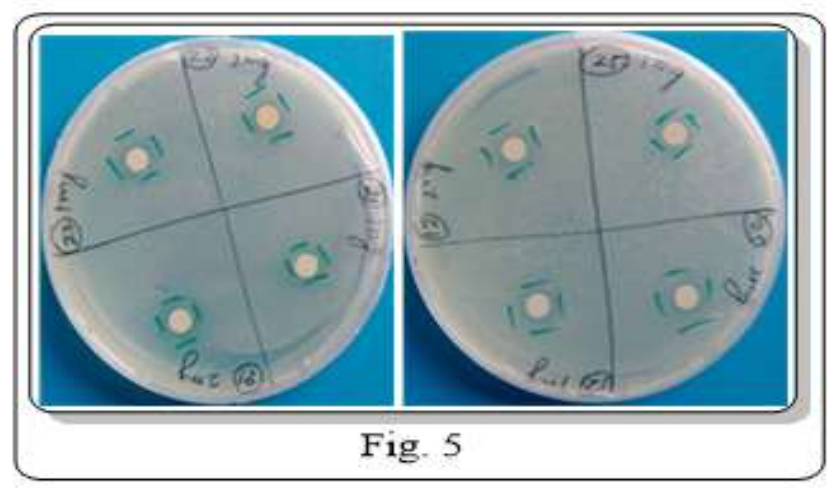

Fig.-5: Zone of Inhibition for Metal Complexes against B. subtilis

These results indicate the antibacterial activity of the ligands more prominent and significant while coordinating with the transition metal ions. We therefore speculate, this increased antimicrobial activity thus could be considered because of the efficient diffusion of the metal complexes in a bacterial cell or further could be interacting with them as consistent with previous studies. ${ }^{30-31}$ In metal complexes, 
RASĀYAN J. Chem.

Vol. 13 | No. 3 |1653-1661| July - September | 2020

Overton's concept and Tweedy's chelation theory can further explain the enhanced biological activities as described previously ${ }^{32}$. As consistent, our results show the dose-dependent patterns as the growth is pace down with lower concentration, while the more inhibitory effect with the higher concentration in both bacterial strains. Furthermore, ZoI of Ni complex thus suggests the higher antibacterial activity as compared to the other synthesized compounds and therefore it could potentially be used for new therapeutic targets.
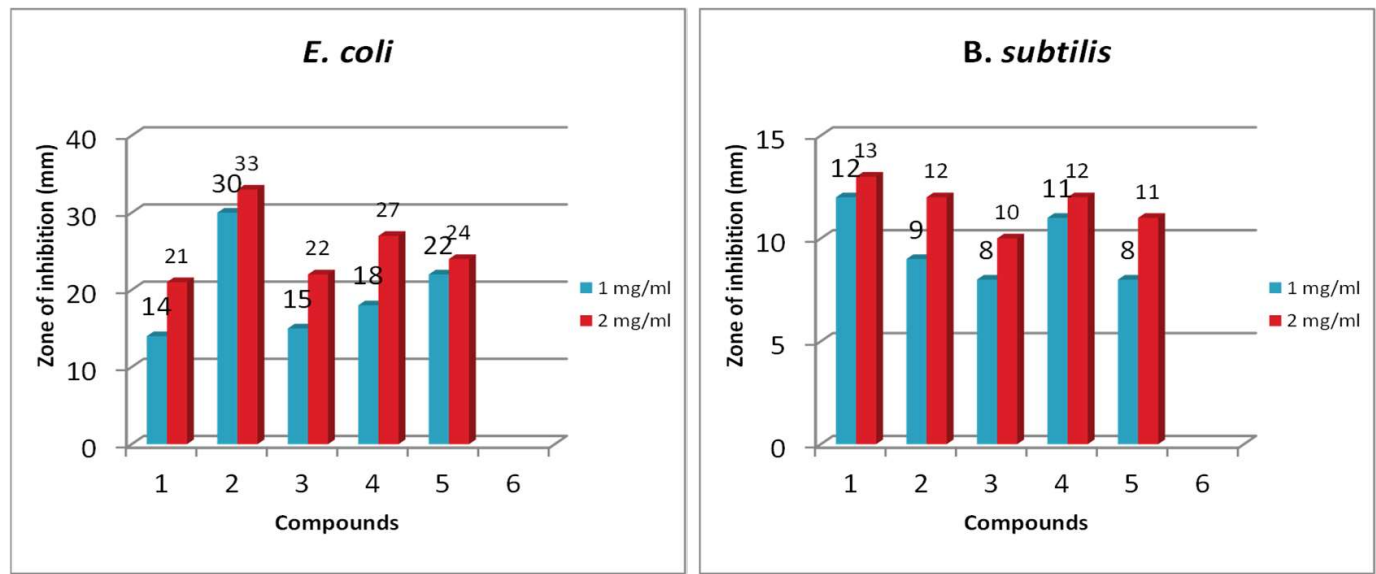

Fig.-6: Comparison of diameters of zone of inhibition for synthesized compounds (1-5) against Gram (-) bacterium (E. coli); and Gram (+) bacterium (B. subtilis) at two different concentrations.

\section{Electrochemical Assessments}

Electrochemical reduction properties of ligand, $\mathrm{Cu}^{\mathrm{II}}$ and $\mathrm{Ni}^{\mathrm{II}}$ complexes were studied at glassy carbon electrode using cyclic voltammetry. Cyclic voltammograms depicted unambiguous irreversible cathodic peaks at $-0.560,-0.521$ and $-0.503 \mathrm{~V}$ for ligand, $\mathrm{Ni}^{\mathrm{II}}$ and $\mathrm{Cu}^{\mathrm{II}}$ complex respectively which can be attributed to the reduction of the groups present in the compound (vs. $\mathrm{Ag} / \mathrm{AgCl}$ reference electrode in $\mathrm{BR}$ buffer). No peaks were observed on the reverse scan, indicating the irreversibility of electrode processes of said compounds. The design of cyclic voltammograms evinced the irreversible nature of reduction of ligand, $\mathrm{Ni}^{\mathrm{II}}$ and $\mathrm{Cu}^{\mathrm{II}}$ complexes as portrayed in Fig.-7. The Cyclic voltammogram of ligand (PTTH) between 0.0 and $-1.0 \mathrm{~V}$ in DMF depicted an unambiguous irreversible cathodic peak at $-0.560 \mathrm{~V}\left(\mathrm{E}_{1 / 2}=-\right.$ $0.450 \mathrm{~V}$ ), which can be attributed to the reduction of the group present in the compound (vs. $\mathrm{Ag} / \mathrm{AgCl}$ reference electrode in BR buffer) (Fig.-7). The Cyclic voltammograms of $\mathrm{Cu}^{\mathrm{II}}$ (between 0.0 and $-0.7 \mathrm{~V}$ ) and $\mathrm{Ni}^{\mathrm{II}}$ (between 0.0 and $-0.8 \mathrm{~V}$; Fig.-7) in DMF also exhibited an unambiguous irreversible cathodic peak at $-0.503\left(\mathrm{E}_{1 / 2}=-0.402 \mathrm{~V}\right)$ and $-0.521\left(\mathrm{E}_{1 / 2}=-0.417 \mathrm{~V}\right)$ respectively, corresponds to the $\mathrm{Cu}(\mathrm{II}) / \mathrm{Cu}(\mathrm{I})$ and $\mathrm{Ni}(\mathrm{II}) / \mathrm{Ni}(\mathrm{I})$.
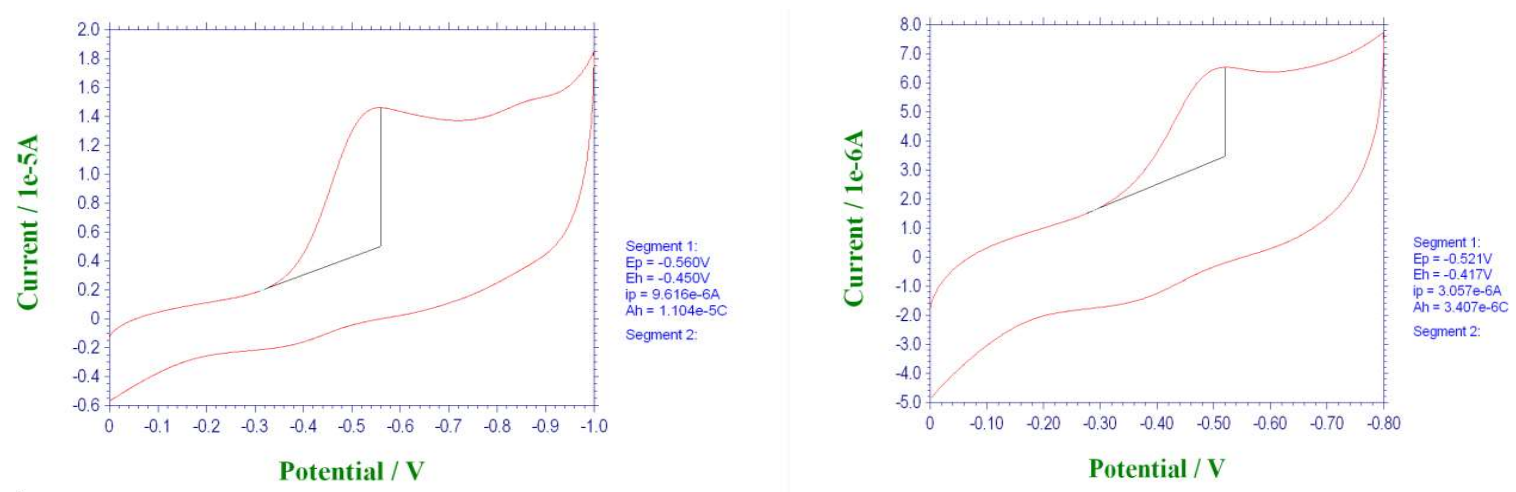

Fig.-7: Cyclic voltammogram of the ligand and $\mathrm{Ni}^{\mathrm{II}}$ complexes. 
RASĀYAN J. Chem.

Vol. 13 | No. 3 |1653-1661| July - September | 2020

\section{CONCLUSION}

SN-donor 1,2,4-triazine ligand (PTTH) and its $\mathrm{Ni}^{\mathrm{II}}, \mathrm{Cu}^{\mathrm{II}}, \mathrm{Zn}^{\mathrm{II}}$, and $\mathrm{Cd}^{\mathrm{II}}$ complexes were successfully prepared and further investigated through elemental analysis, ${ }^{1} \mathrm{H}-\mathrm{NMR}$, FT-IR and LC-MS spectral studies. The results indicate that, ligand acts as a mono-functional bidentate and it coordinates via deprotonated nitrogen and sulphur donor to the metal ion to afford the corresponding complexes 2 to 5 giving a four-member stable chelate ring. Antibacterial activities towards two bacterial strains, namely Bacillus subtilis (MTCC-121) and Escherichia coli (MTCC-40) were screened, and the results revealed significantly more activity for these newly synthesized derivatives as compared to free 1,2,4-triazine (PTTH) ligand. Therefore, it is suggested that the coordination of said ligand (PTTH) with different metal ions makes them stronger bacteriostatic agents, thus inhibiting the growth of bacteria more than the parent ligand. Furthermore, preliminary electrochemical results confer good prospects to elucidate the possible cathodic process for ligand, $\mathrm{Ni}^{\mathrm{II}}$ and $\mathrm{Cu}^{\mathrm{II}}$ complexes.

\section{ACKNOWLEDGEMENT}

The authors are thankful to the Head, Department of Chemistry, for providing the necessary research facilities. This study received financial assistance from the University Grant Commission, New Delhi through JRF during the research work progressed. We are also grateful to USIC (University Science Instrumentation Centre), MNIT Jaipur and Therachem lab Jaipur for providing analytical and spectral data.

\section{REFERENCES}

1. A. S. Abd-El-All, A. A. Labib, H. A. Mousa, F. A. Bassyouni, K. H. Hegab, M. A. El-Hashash, S. R. Atta-Allah, W. H. AbdEl-Hady and S. A. M. Osman, Journal of Applied Sciences Research, 9(1), 469 (2013).

2. G. A. Elmegeed, A. R. Baiuomy, M. M. Abdelhalim and H. Y. Hana, Arch Pharm Chemistry in Life Sciences, 343, 261(2010), DOI:10.1002/ardp.200900244

3. A. G. Banerjee, N. Das, S. A. Shengule, R. S. Srivastava and S. K. Shrivastava, European Journal of Medicinal Chemistry, 101, 81(2015), DOI:10.1016/j.ejmech.2015.06.020

4. D. R. Kerzarea and P. B. Khedekar, Journal of Pharmaceutical Science and Bioscientific Research, 6(1), 144 (2016).

5. M. A. El-Hashash, S. A. Rizk and A. A. El-Sayed, Journal of Advances in Chemistry, 13(12), 6130 (2017), DOI:10.24297/jac.v13i12.6188

6. T. E. Olalekan, A. S. Ogunlaja and G. M. Watkins, Heteroatom Chemistry, 1(2019), DOI: $10.1155 / 2019 / 9203435$

7. M. M. Mashaly, H. F. El-Shafiy, S. B. El-Maraghy and H. A. Habib, Spectrochimica Acta Part A, 61, 1853 (2005), DOI:10.1016/j.saa.2004.06.056

8. R. M. Zaki, A. M. K. El-Dean, S. M. Radwan and A. F. Saber, Journal of the Brazilian Chemical Society, 29(12), 2482 (2018), DOI:10.21577/0103-5053.20180127

9. S. Dadashpour, T. T. Kucukkilinc, O. U. Tan, K. Ozadali, H. Irannejad and S. Emami, Arch Pharm Chemistry in Life Sciences, 348, 179(2015), DOI:10.1002/ardp.201400400

10. I. Karpenko, S. Deev, O. Kiselev, V. Charushin, V. Rusinov, E. Ulomsky, E. Deeva, D. Yanvarev, A. Ivanov, O. Smirnova, S. Kochetkov, O. Chupakhin, M. Kukhanova. Antimicrobial Agents and Chemotherapy, 54(5), 2017 (2010), DOI:10.1128/AAC.01186-09

11. M. Mojzych, Z. Bernat, Z. Karczmarzyk, J. Matysiak and A. Fruziński, Molecules, 25, 1(2020), DOI: 10.3390/molecules25010221

12. M. S. T. Makki, R. M. A. Rahman and O. A. A. Ali, International Journal of Organic Chemistry, 5(3), 153 (2015), DOI: 10.4236/ijoc.2015.53017

13. K. Ban, S. Duffy, Y. Khakham, V. M. Avery, A. Hughes, O. Montagnat, K. Katneni, E. Ryan and J. B. Baell, Bioorganic \& Medicinal Chemistry Letters, 20, 6024(2010), DOI: 10.1016/j.bmcl.2010.08.065

14. D. Branowska, J. Ławecka, M. Sobiczewski, Z. Karczmarzyk, W. Wysocki, E. Wolińska, E. Olender, B. Mirosław, A. Perzyna, A. Bielawska and K. Bielawski, Monatsh Chem, 149, 1409(2018), DOI: $10.1007 / \mathrm{s} 00706-018-2206-\mathrm{y}$ 
RASĀYAN J. Chem.

Vol. 13 | No. 3 |1653-1661| July - September | 2020

15. N. P. Prajapati and H. D Patel, Synthetic Communications, 49, 2767(2019), DOI: 10.1080/00397911.2019.1649432

16. S. Chandra, Sangeetika and S. Thakur, Transition Metal Chemistry, 29, 925(2004), DOI: 10.1007/s1 1243-004-3224-7

17. U. M. Aswar, P. P. Kalshetti, S. M. Shelke, S. H. Bhosale and S. L. Bodhankar, Asian Pacific Journal of Tropical Biomedicine, 2(12), 992 (2012), DOI:10.1016/S2221-1691(13)60012-X

18. I. F. Nassar, Journal of Heterocyclic Chemistry, 50(1), 129 (2013), DOI:10.1002/jhet.1022

19. G. G. Berest, O. Y. Voskoboynik, S. I. Kovalenko, O. M. Antypenko, I. S. Nosulenko, A. M. Katsev and O. S. Shandrovskaya, European Journal of Medicinal Chemistry, 46(12), 6066(2011), DOI: 10.1016/j.ejmech.2011.10.022

20. H. A. Saad, M. M. Youssef and M. A. Mosselhi, Molecules, 16(6), 4937(2011), DOI: 10.3390/molecules 16064937

21. A. Gouranourimi, M. Ghassemzadeh, S. Bahemmat, B. Neumuller and R. Tonner, Monatsh Chem., 146, 57 (2015), DOI: 10.1007/s00706-014-1280-z

22. M. A. Blanco, E. Lopez-Torres, M. A. Mendiola, E. Brunet and M. T. Sevilla, Tetrahedron, 58, 1525 (2002), DOI: 10.1016/S0040-4020(02)00016-9

23. E. Lopez-Torres and M. A. Mendiola, Polyhedron, 24, 1435(2005), DOI:10.1016/j.poly.2005.03.093

24. E. Lopez-Torres, M. A. Mendiola and C. J. Pastor, Inorganic Chemistry, 45(7), 3103(2006), DOI: $10.1021 / \mathrm{ic} 052009 \mathrm{~d}$

25. E. Lopez-Torres, M. A. Mendiola and C. J. Pastor, Polyhedron, 25, 1464(2006), DOI10.1016/j.poly.2005.10.013

26. H. A. Riley and A. R. Gray, Organic Syntheses, 15, 67 (1935), DOI:10.15227/orgsyn.015.0067

27. A. I. Vogel, Text Book of Quantitative Chemical Analysis, London:Longmans, Addison Wesley, (1999).

28. K. C. Joshi, K. Dubey and A. Dandia Heterocycles, 16 (9), 1545(1981).

29. M. Tisler, Croatica Chemica Acta, 32, 123(1960).

30. S. Beniwal, S. Chhimpa, D. Gaur, P. J. John, Y. Singh and J. Sharma, Applied Organometallic Chemistry, 31(10), ( 2016), DOI:10.1002/aoc.3725

31. A. W. Bauer, W. M. M. Kirby, J. C. Sherris and M. Turck, The American Journal of Clinical Pathology, 45, 493(1966).

32. B. G. Tweedy, Phytopatology, 55, 910(1964).

[RJC-5846/2020] 